\title{
The Development of /-Cylearn Framework in Online Digital Learning in Higher Education: The Fuzzy Delphi Method Study
}

Ramlan Mustapha, M. Fairuz Jafar, M. Muzakkir Othman, M. Kamal Jusoh \& Nur Shahira Ibrahim

To Link this Article: http://dx.doi.org/10.6007/IJARBSS/v11-i4/9681

DOI:10.6007/IJARBSS/v11-i4/9681

Received: 02 February 2021, Revised: 05 March 2021, Accepted: 29 March 2021

Published Online: 20 April 2021

In-Text Citation: (Mustapha et al., 2021)

To Cite this Article: Mustapha, R., Jafar, M. F., Othman, M. M., Jusoh, M. K., \& Ibrahim, N. S. (2021). The Development of I-Cylearn Framework in Online Digital Learning in Higher Education: The Fuzzy Delphi Method Study. International Journal of Academic Research in Business and Social Sciences, 11(4), 412-428.

Copyright: @ 2021 The Author(s)

Published by Human Resource Management Academic Research Society (www.hrmars.com)

This article is published under the Creative Commons Attribution (CC BY 4.0) license. Anyone may reproduce, distribute, translate and create derivative works of this article (for both commercial and non-commercial purposes), subject to full attribution to the original publication and authors. The full terms of this license may be seen at: http://creativecommons.org/licences/by/4.0/legalcode

Vol. 11, No. 4, 2021, Pg. 412 - 428

Full Terms \& Conditions of access and use can be found at http://hrmars.com/index.php/pages/detail/publication-ethics 


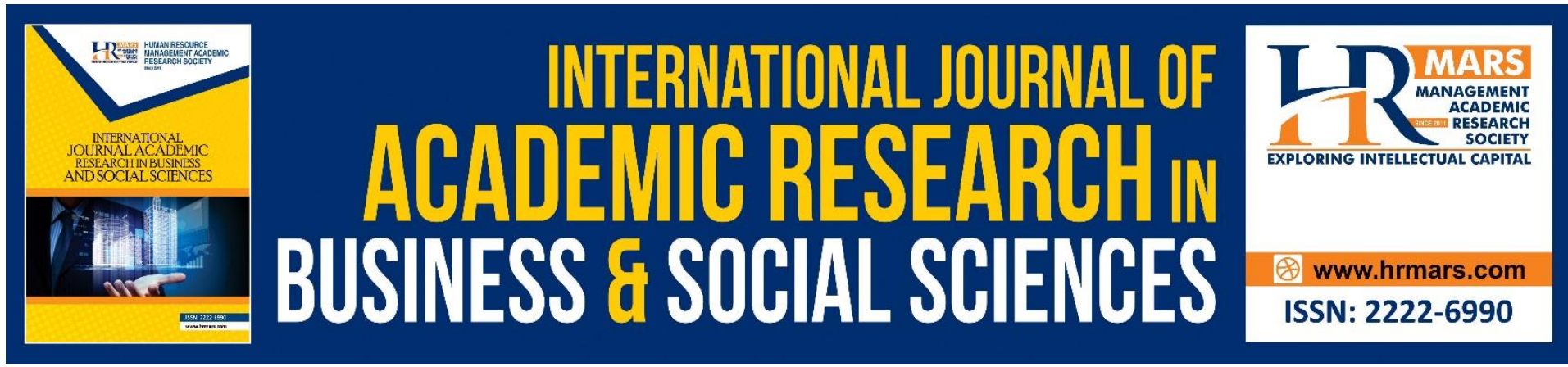

\title{
The Development of I-Cylearn Framework in Online Digital Learning in Higher Education: The Fuzzy Delphi Method Study
}

\author{
${ }^{1}$ Ramlan Mustapha, ${ }^{2} \mathrm{M}$. Fairus Jafar, ${ }^{3} \mathrm{M}$. Muzakkir Othman, \\ ${ }^{4} \mathrm{M}$. Kamal Jusoh \& ${ }^{5}$ Nur Shahira Ibrahim \\ ${ }^{1}$ Universiti Teknologi MARA Pahang, Raub Campus, ${ }^{3,4,5}$ Universiti Teknologi MARA Pahang, \\ Jengka Campus, ${ }^{2}$ Universiti Utara Malaysia, Malaysia \\ Email: ramlan@uitm.edu.my
}

\begin{abstract}
This study aims at getting expert consensus and opinions on elements of the online learning framework in higher education. This study uses 7 expert scale to gather input from 11 experts in different education fields at public universities in Malaysia using Fuzzy Delphi process. The assessment received a total of 3 key construct and 18 sub-elements of the questionnaire. The Fuzzy Delphi method Logic Software (FUDELO) has been used for data analysis. The data were analysed using a triangle fuzzy number and a ranking of the defuzzification process with each construct elements. The results of the study and the consensus of the experts show that the Agreement's value is in a good level. This shows that elements of the online digital learning framework have been well-received by experts. The elements agreed upon by the experts in consensus are arranged in order of ranking namely emotional factor, cognitive factor and social factor.
\end{abstract}

Keyword: Fuzzy Delphi Method, Framework, I-CyLearn, Defuzzification, Digital Learning

\section{Introduction}

Technology plays an essential part in our everyday lives in the 21st century. In order to use technology in the re-design or regeneration of education and training systems, it requires professionally, educated people and learners to re-reflect their fundamental values. Moreover, these technical devices have an important role in allowing students and teachers to achieve more benefits from it. However, e-learning, mobile learning and remote learning are used in an oblivious or complementary manner to denote technical learning (Basak, Wotto \& Belanger, 2018).

The rapid development of technology, demands that all individuals move fast in adapting technology in life. Among the sectors affected by the rapid development of technology is the world of education. The broad use of internet and institutional e-learning systems by private providers has given students a new versatile and portable opportunity for the acquisition of information and the dissemination of knowledge (Al-Emran \& Mezhuyev, 2019; Al-Emran \& Teo, 2019). E-learning platforms allow students to connect simultaneously with educators and 
classmates through many media including email, live video, file sharing and live blogs (Kim et al., 2017).

In this context, the generation of new learning environments and methodologies has been made possible by emerging technical means (Belmonte, Robles, Guerrero \& Gonzalez, 2020). They also encouraged the implementation of a variety of digital and creative tools to support the teaching actions carried out between lecturers and students and encourage them. Elearning has shortcomings or disadvantages among potentialities that are mirrored (Ramos et al., 2020). This new approach eliminates physical interaction between individuals (Uppal \& Gulliver, 2018). For it to evolve effectively (computer, mobile devices and Internet access, among others) a range of technical specifications is needed (Hubalovsky, Hubalovsk, \& Musilek, 2019).

\section{Cybergogy}

Cybergogy is a method of Education in the era of globalization through the empowerment of Information and Communication Technology (ICT) that is unlimited from space, time, culture and country (Daud et al., 2019). Students and lecturers easily obtain material, learning modules from various references via the internet (Malek, 2017) so as to produce more interesting collaborative learning (Dailey-Hebert \& Dennis, 2015). Cybergogy approach in teaching and learning directs learners that learning can be done anywhere and anytime in accordance with their respective conditions in accessing computers and the internet, the availability of highly complete and heterogeneous subject matter on the internet can be accessed easily by learners. With technology 4.0 era teaching and learning communication services between lecturers and students have been facilitated using e-learning, collaborative learning strategies can be facilitated with video and audio sharing or blogging, web GitHub also facilitates learners in teamwork communication to compile a joint project. Cybergogy also facilitates learning through communities by activating participants in building discussions, conveying ideas, negotiating and finding solutions with the community (Bilfaqih \& Qomarudin, 2015).

Cybergogy is an educational method in which teachers instruct students to learn online through programmes and resources created by thousands of Internet providers. It is a descriptive label for methods for online active learning (Wang, 2007; Yusuf \& Yusuf, 2018). The foundation of cybergogy is awareness of the techniques under which facet learning is not the same as simulated environmental learning. The educators who are educated about the usage of the online computer systems recently used this style of pedagogy intensively. The teachers who are digitally illiterate are one of the big issues in applying these methods (Yusuf et.al, 2018). Therefore, understanding and training to introduce this modern technology to educators is important especially in institutions of higher learning. The rapid use of gadgets, social media and the internet is seen to have a high impact on the world of education. Therefore, educators, lecturers and teacher educators need to take the opportunity in leveraging technology in order to help teaching more effectively.

\section{E Learning in Malaysia}

Malaysia is one of the fastest growing countries. The rapid development of technology in all sectors creates an electronic environment in all angles, including education. The Malaysian government through the Ministry of Higher Education has introduced various e -learning mediums, including those funded by the government and the private sector. By the technology acceptance among younger generations, the Malaysia Government is moving 
towards promoting online education and providing accessible and practical education to address lack of quality education. The Government's strong initiative allows students to join the ongoing demand expansion growth of the online higher education network (Ullah et al., 2017, Mustapha et al, 2021).

The Malaysia National E-Learning policy for higher education institutions refers to the initiative to establish the high-quality electronic education system and guidelines for the "One Malaysia" concept (Model Baru Ekonomi-MBE, Malaysia Higher Education Ministry 2011). The key components of electronic learning, such as LMS, content management systems and materials management, are used in E-Learning. In the course of the evolution of education technology, numerous ICT specialists introduce in their schoolroom new technologies that alter the world in which they teach (Mustapha et al., 2021). Moreover e-learning can be available everywhere through the use of networking platforms such as smart phones, through the implementation of electronic learning management systems (Kassim \& Khalid, 2016). The Malayan Education Blueprint, a comprehensive action plan that charts the education environment from 2013 to 2025, has recently been released in Malaysia. Achieving the difference to produce a more technologically skilful staff, one appropriate to the expertise and skills of the 21st century, 11 steps have been found to bring about the transformation in the outcomes of education envisaged by all Malaysians.

In addition, Ministry Higher education Malaysia plays an important role in the creation of OLL in the learning phase. In their courses as well as face-to-face teaching, most higher education institutions in Malaysia are encouraged to develop an interactive e-learning system called LMS, which provides a mixed learning atmosphere for their student (Tayebinik \& Puteh, 2012; Mustapha et al, 2021). Based on this initiative, the researcher felt that there should be a specific guideline in the implementation of e learning in Malaysia. Based on the literature review made by the researcher, there is no specific guideline on social network learning that includes e learning at the tertiary level. Therefore, based on this gap, the researcher tries to build a guide that may be used as a reference in higher education, especially among instructors and lecturers.

\section{The Significant of the Study}

The development of online learning encourages a variety of learning methods. However, as the time comes, there is already some doubt about the various technical learning methods. E-learning, m-learning and d-learning are not often properly used because they intersect with some interactive uses for learning. For instructors, academics, coaches, pupils, etc., the similitudes and discrepancies between e-learning, m-learning and learning need explained to address instructional and learning challenges and to enhance learning outcomes correlated with the current situation in real life. However, the researcher did not find a framework that can be an activity guide or reference in implementing this online or digital activity. As a result of the researcher's observation and reading, there is a gap that can be filled by the researcher by building a guideline in the implementation of this online digital learning.

\section{The Aim of the Study}

The aim of this study is to develop the framework in online digital learning based on expert consensus. 


\section{Methodology}

This study essentially uses the Multi Research Method approach introduced by Richie \& Klein (2007). Design and Development Research is well known as one of the research methods used by many researchers in development studies based on the construction of prototypes, models, frameworks and many more that can be adapted to the objectives and motives of the study. However, the researcher made certain modifications to adapt to this study as the researcher did not have long time to complete it.

Basically, this study contains two main phases, namely the first phase of the researcher making the relevant literature highlights to remove the main constructs and items needed in the formation of the I-Cylearn framework. Then the researcher proceeded to phase 2 which is the use of Fuzzy Delphi Method which is centered on expert consensus. Fuzzy Delphi Method is a systematic method of getting an agreement on something to build. At this second stage, the researcher distributes an expert consent evaluation instrument to the constructed framework item. Once the data is obtained the researcher processes the data using Fudelo 1.0 software. (Fuzzy Delphi Logic software). Once the data is analysed, the i-Cylearn Successful framework is formed based on expert consent.

\section{Sampling Technique}

This study uses purposive sampling. This method is best suited because the researcher wants to reach agreement on something developed. According to Hasson, Keeney \& McKenna (2000) the most appropriate method in FDM is purposive sampling .This study was attended, meanwhile, by a total of 11 experts. The participating experts are described in Table 2 . These experts are selected based on their respective experience and expertise. If the expert involved in this study is homogenous, the number of specialists required is 5 to 10 . The required number of Delphi experts is from 10 to 15 people when there are a uniformity degree Adler \& Ziglio (1996). While collecting data, researchers take into account several important factors such as difficulty in getting an appointment with an expert and also time constraints. Therefore the researcher is only able to access only 11 experts. However, this amount is sufficient for the data of this study.

Table 2: Expert List

\begin{tabular}{|l|c|l|l|}
\multicolumn{1}{|c|}{ Expert list } & \multicolumn{1}{c|}{$\begin{array}{c}\text { Total } \\
\text { expert }\end{array}$} & \multicolumn{1}{c|}{ Field of expertise } \\
Professor & 1 & Computer Science/education & Public University \\
Ass Professor & 2 & Multimedia/education & \\
Senior Lecturer & 4 & Computer science/education & \\
Lecturer & 2 & Education & Public School \\
Islamic education & 2 & Islamic education & \\
teacher & & & \\
\hline
\end{tabular}

\section{Who is expert (expert criteria)}

The experts are trained, knowledgeable and knowledgeable people, based on training, practise and experience they have gained, Booker \& Mc Namara (2004). Specialists are normally identified on the basis of their skills, training, experience, professional membership and peer recognition (Nikolopoulus, 2004; Perera, Drew \& Johnson, 2012). An expert is a person with a certain level of experience, knowledge of the subject or field (Cantrill, Sibbald \& Buetow, 1996; Mullen, 2003). One of the important aspects to consider in the Fuzzy Delphi 
study is the element of expert selection. Issues such as validity, validity and reliability of the analysis results and conclusions may be disputed where expert selection is made inaccurately and on the basis of certain criteria (Mustapha \& Darusalam, 2017). In the method of Delphi or Fuzzy Delphi, it is essential, in principle in determining the quality, accuracy and credibility of the results reached, to select experts and to select experts accurately. In order to achieve the sense, the accuracy, and the quality of Delphi (Dalkey \& Helmer, 1963; Linstone, 2002). On the basis of very strict selection criteria, the researcher selects experts with 7 years of experience and above, and experts who are exactly right with their field of expertise and with regard to the study.

\section{Research Instrument}

The researcher developed the test instrument for Fuzzy Delphi on the basis of the literary research. Based on Skulmowski, Hartman \& Krahn (2007), literature, pilot studies and experience may be used to form the forming of questionnaire elements. In the meantime Mustapha \& Darussalam (2017) have reported that questions for the technique from Fuzzy Delphi have been formulated on the basis of research points, expert interviews and focus group techniques. In addition, the development of the items and the component elements of a sample should be carried out in the presence of a review of the literature (Okoli and Pawlowski, 2004). Researchers therefore use literature to acquire the $\mathrm{i}$-cylearn model components.

Thereafter, a series of expert questions is formed using a 7-point scale. Choosing the 7-point scale was preferred because the greater the number of scales, the more precise and accurate the data collected (Chen, Hsu \& Chang, 2011). The researcher place value between 1 to 7 to replace the Fuzzy value as shown in Table 4 for the following 7-point linguistic scale to make it much easier for the experts to answer the questionnaire.

Table 3: Fuzzy number

\begin{tabular}{|l|c|}
\hline Item & Fuzzy number \\
\hline Strongly Disagree & $(0.0 .0 .0,0.1)$ \\
\hline Disagree & $(0.0,0.1,0.3)$ \\
\hline Somewhat Disagree & $(0.0,0.3,0.5)$ \\
\hline Neither agree or disagree & $(0.3,0.5,0.7)$ \\
\hline Somewhat agree & $(0.5,0.7,0.9)$ \\
\hline Agree & $(0.7,0.9,1.0)$ \\
\hline Strongly agree & $(0.9,1.0,1.0)$ \\
\hline
\end{tabular}


Table 4: Steps in implementing Fuzzy Delphi Method

\section{Step Formulation}

1. Expert selection

- In this study a total of 11 experts were used. A number of experts were invited to determine the importance of the evaluation criteria on the variables to be measured using linguistic variables. and descriptions of issues that may exist in the item and so on

2. Determining linguistic scale
- This process involves the process of converting all linguistic variables into the numbering of fuzzy triangles (triangular fuzzy numbers). This step also involves the conversion of linguistic variables with the addition of fuzzy numbers (Hsieh, Lu and Tzeng, 2004). Triangular Fuzzy Number represents $\mathrm{m} 1, \mathrm{~m} 2$ and $\mathrm{m} 3$ values and it is written like this ( $\mathrm{m} 1, \mathrm{~m} 2, \mathrm{~m} 3)$. The value of $\mathrm{m} 1$ represents the minimum value, the value of $\mathrm{m} 2$ represents the reasonable value while the value of $m 3$ represents the maximum value. While Triangular Fuzzy Number is used to produce Fuzzy scale for the purpose of translating linguistic variables into fuzzy numbers. The number of levels for the Fuzzy scale is in odd numbers. It can be explained in Figure 1

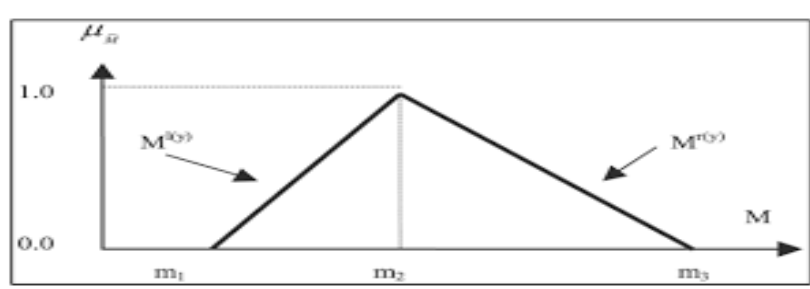

Figure 1: Triangular fuzzy number

3. The Determination of Linguistic Variables and Average Responses
- Once the researcher receives a feedback from the specified expert, the researcher needs to turn all measurement results to Fuzzy scales. This process is also known as the recognition of each response (Benitez, Martin \& Roman, 2007).

4. The determination of threshold value "d"
- The threshold value is very important in the process of identifying the level of agreement among experts (Thomaidis, Nikitakos \& Dounias, 2006). The distances for each fuzzy number $m=$ $(\mathrm{m} 1, \mathrm{~m} 2, \mathrm{~m} 3)$ and $\mathrm{n}=(\mathrm{m} 1, \mathrm{~m} 2, \mathrm{~m} 3)$ are calculated using the formula:

$d(\bar{m}, \bar{n})=\sqrt{\frac{1}{3}\left[(m 1-n 1)^{2}+(m 2-n 2)^{2}+(m 3-n 3)^{2}\right]}$ 


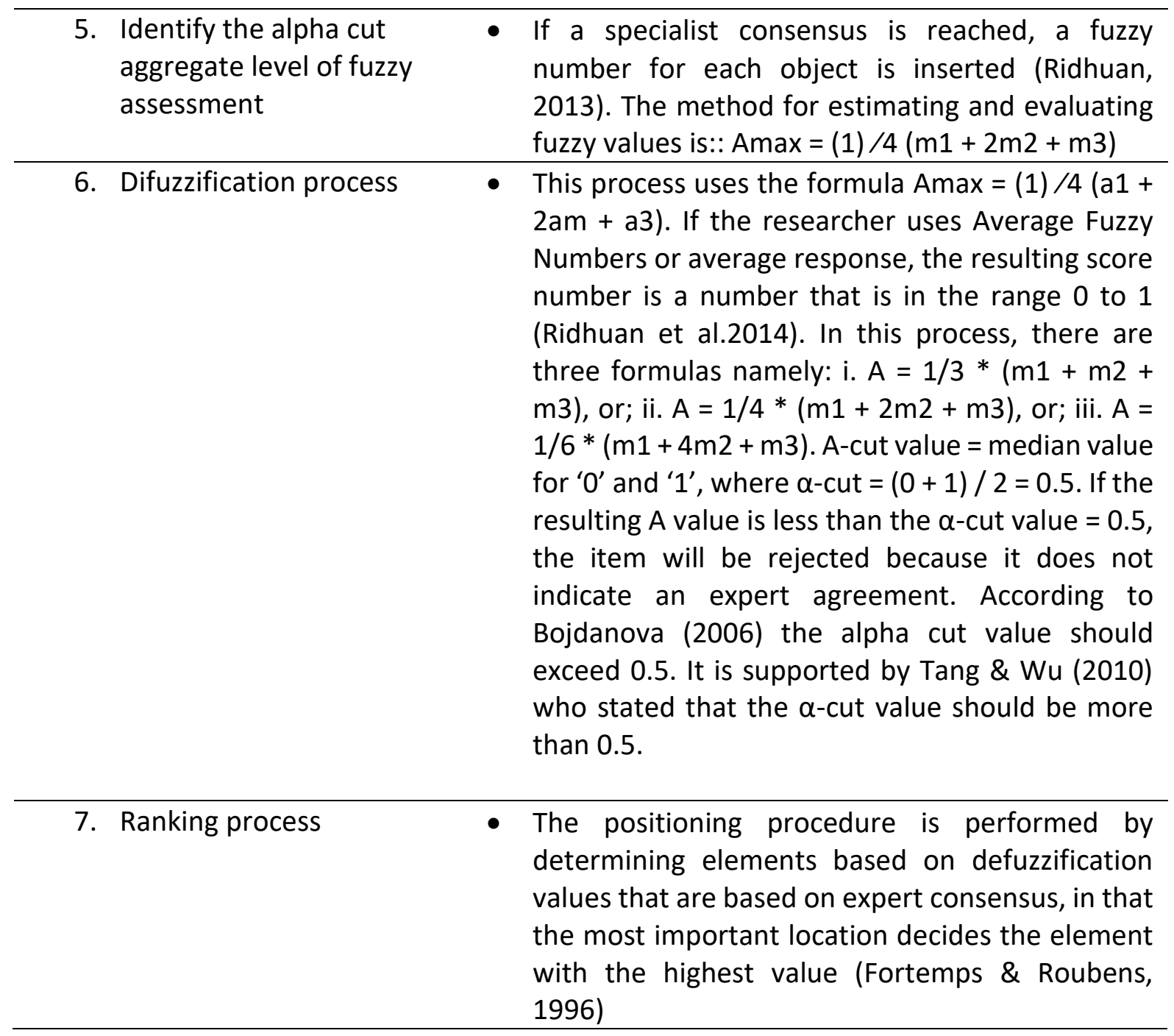

\section{The Development of I Cylearn Framework Elements}

At this stage, the researcher shapes the elements in the I-cylearn framework using a literature review approach. After the research is made based on some literature that is scrutinized in detail the researcher collects these elements and arranged in order to be evaluated by experts. The elements of the study are as follows:

Table 5: Model elements

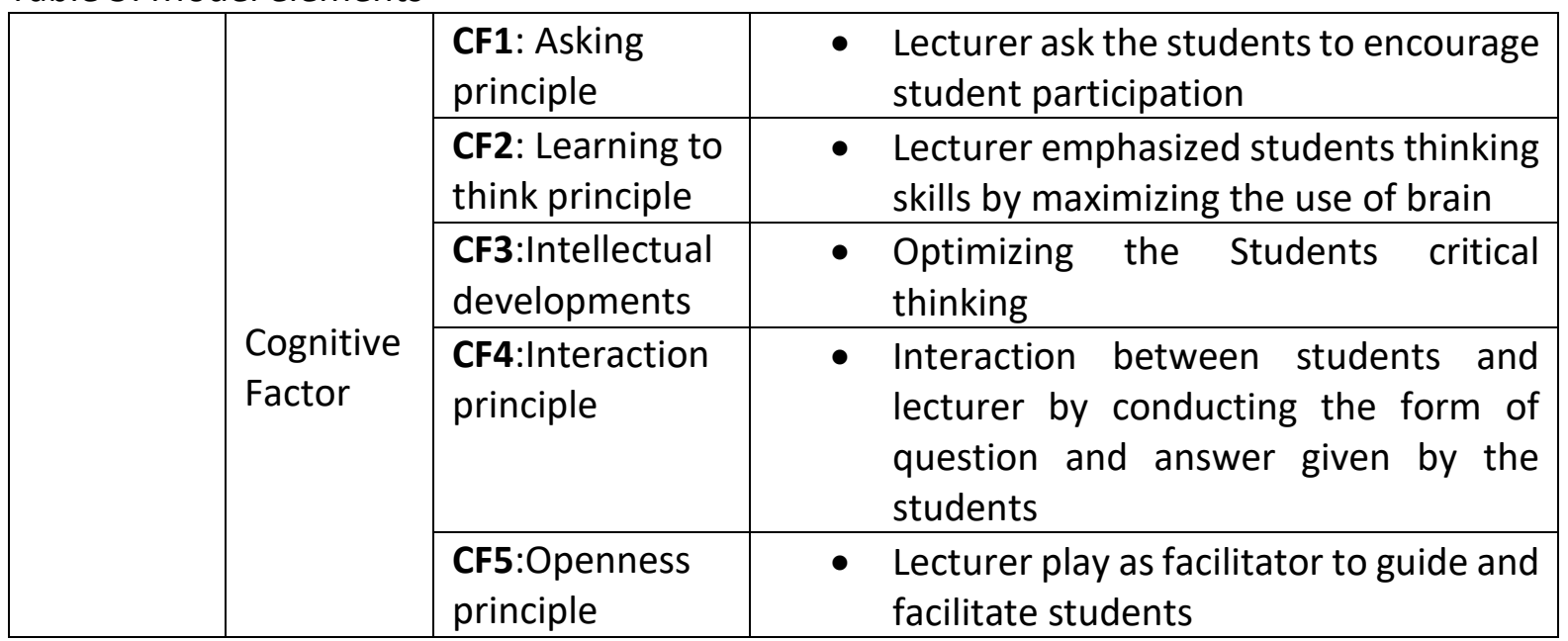




\begin{tabular}{|c|c|c|c|}
\hline \multirow[t]{9}{*}{$\begin{array}{l}\text { I-cylearn } \\
\text { model }\end{array}$} & $\begin{array}{l}\text { Emotional } \\
\text { Factor }\end{array}$ & \multicolumn{2}{|c|}{$\begin{array}{l}\text { EF1: Lecturer control social emotional interaction } \\
\text { EF2: Detection of emotional conflict } \\
\text { EF3: Reward processing and reinforcement } \\
\text { EF4: Active maintenance of valence information } \\
\text { EF5: Increase active response to positive emotion }\end{array}$} \\
\hline & \multirow{8}{*}{$\begin{array}{l}\text { Social } \\
\text { Factor }\end{array}$} & $\begin{array}{l}\text { SF1: Delivering } \\
\text { the assignment } \\
\text { of observation } \\
\text { \& the rule of } \\
\text { practice }\end{array}$ & $\begin{array}{l}\text { - The lecturer explains the rules } \\
\text { consisting of: Goal of activity, pairing } \\
\text { the students, procedure, time } \\
\text { allocation for the activity }\end{array}$ \\
\hline & & $\begin{array}{l}\text { SF2: Finding the } \\
\text { learning partner }\end{array}$ & $\begin{array}{l}\text { - Students autonomously find their } \\
\text { learning partners around the campus } \\
\text { or their houses }\end{array}$ \\
\hline & & $\begin{array}{l}\text { SF3: Initial } \\
\text { Observation }\end{array}$ & $\begin{array}{l}\text { - Students introduce themselves \& their } \\
\text { objectives to their learning partners \& } \\
\text { negotiate time and procedure of the } \\
\text { participatory observation }\end{array}$ \\
\hline & & $\begin{array}{l}\text { SF4: Performing } \\
\text { the } \\
\text { participatory } \\
\text { observations }\end{array}$ & $\begin{array}{l}\text { - Students act as if they are the learning } \\
\text { partners, make informal interview } \\
\text { about daily activities of their learning } \\
\text { partners etc. }\end{array}$ \\
\hline & & $\begin{array}{l}\text { SF5: Preparing } \\
\text { \& giving a } \\
\text { presentations }\end{array}$ & $\begin{array}{l}\text { - Students thanks their learning partners } \\
\text { \& giving them presents }\end{array}$ \\
\hline & & $\begin{array}{l}\text { SF6: } \text { Reflection, } \\
\text { reporting \& } \\
\text { presentation }\end{array}$ & $\begin{array}{l}\text { - Students make reflections of the } \\
\text { completed activities, make reports in } \\
\text { the classroom. }\end{array}$ \\
\hline & & $\begin{array}{l}\text { SF7: } \\
\text { Reinforcement }\end{array}$ & $\begin{array}{l}\text { - The lecturer gives some responses to } \\
\text { reinforce positive refection \& reports } \\
\text { of the students }\end{array}$ \\
\hline & & SF8: Evaluation & $\begin{array}{l}\text { - The Lecturer evaluates students } \\
\text { report, performance \& attitude }\end{array}$ \\
\hline
\end{tabular}

\section{Finding}

In this part, the researcher will present the research findings based on the consensus of the experts with reference to the elements or criteria for the implementation of I-cylearn in higher education. The results were collected on the basis of 11 sets Fuzzy Delphi questionnaires, which were sent to 11 experts. The research findings are the following: 


\section{The Result of FDM1 (Construct Rank)}

Table 6: result of construct rank

\begin{tabular}{|c|c|c|c|}
\hline Results & Cognitive factor & Emotional factor & Social Factor \\
\hline Expert1 & 0.00525 & 0.01575 & 0.04199 \\
\hline Expert2 & 0.06298 & 0.01575 & 0.01575 \\
\hline Expert3 & 0.00525 & 0.04199 & 0.01575 \\
\hline Expert4 & 0.22569 & 0.01575 & 0.04199 \\
\hline Expert5 & 0.00525 & 0.01575 & 0.04199 \\
\hline Expert6 & 0.06298 & 0.04199 & 0.01575 \\
\hline Expert7 & 0.06298 & 0.01575 & 0.01575 \\
\hline Expert8 & 0.06298 & 0.01575 & 0.01575 \\
\hline Expert9 & 0.11022 & 0.04199 & 0.01575 \\
\hline Expert10 & 0.06298 & 0.01575 & 0.01575 \\
\hline Expert11 & 0.00525 & 0.01575 & 0.01575 \\
\hline Statistics & Item1 & Item2 & Item3 \\
\hline Value of the item & 0.06107 & 0.02291 & 0.02291 \\
\hline Value of the construct & & 0.03563 & \\
\hline Item $<0.2$ & 10 & 11 & 11 \\
\hline$\%$ of item $<0.2$ & $90 \%$ & $100 \%$ & $100 \%$ \\
\hline Average of $\%$ consensus & & 96 & \\
\hline Defuzzification & 0.89091 & 0.97273 & 0.93273 \\
\hline Ranking & 3 & 1 & 2 \\
\hline Status & Accept & Accept & Accept \\
\hline
\end{tabular}

The value of the blackened threshold reaches the $0.2(>0.2)$ threshold following the data review (reference to Table 6). This suggests that experts' views are inconsistent or does not reach the consensus on some issues. The average value of all elements of I-Cylearn indicates a (d) $<0.2$ threshold of 0.03563 . The item has reached a strong expert consensus if the average threshold value (d) is less than 0.2. (Cheng \& Lin, 2002; Chang, Hsu \& Chang, 2011). In the meantime, the total share of the expert agreement is $85 \%$ more than $(>75 \%)$ to fulfil the requirements of the expert agreement on this point.

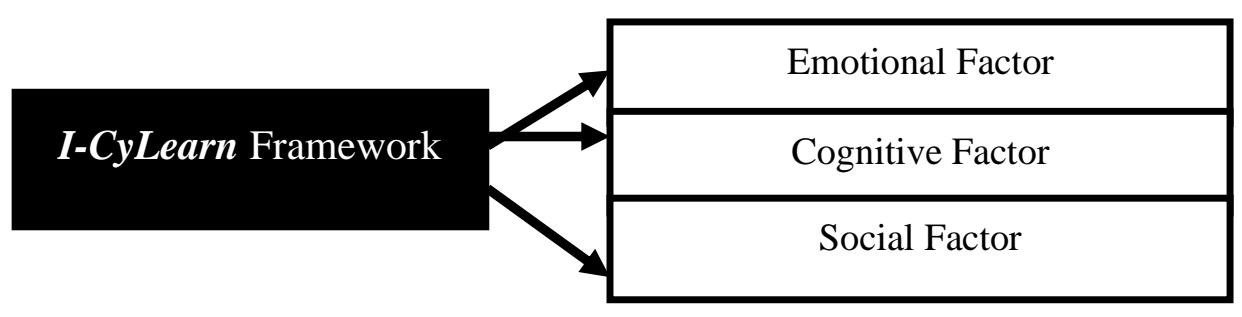

Figure 1: The I-cyLearn Framework Model output

Referring to table 7, shows the results of item data analysis in all three study constructs. Each item analysed passed the value specified in the FDM analysis. As a result of data analysis, (refer to table 7), the bold threshold value exceeds the threshold value $0.2(>0.2)$. This means that there are experts' opinions that are not in line or even and do not reach consensus on certain items. However, the average value of all items of I-CyLearn framework shows a threshold value (d) $<0.2$ which is 0.0532 for Social factor, 0.0439 for Cognitive factor and 
0.0397 for emotional factor construct. If the average value of threshold (d) is obtained less than 0.2, then the item has reached a good expert consensus (Cheng \& Lin, 2002; Chang, Hsu \& Chang, 2011). Meanwhile, the overall percentage of expert agreement is at a value of $97 \%$ for social factor, $96 \%$ for cognitive factor and $98 \%$ for emotional factor agreement which is more than (> 75\%) means to meet the conditions of expert agreement on this item. In addition, all Alpha-Cut defuzzification values (average of fuzzy response) exceed $\alpha$-cut $=>0.5$. According to (Tang \& Wu, 2010; Bojdanova, 2006)) the alpha cut value should exceed 0.5 and if it is less than 0.5 , then it should be dropped. The findings of this analysis show that the $1-$ CyLearn framework and construct have received good expert agreement. The items agreed upon by the consensus of experts are arranged according to priority (ranking) as shown on table 8 and figure 2 . 
INTERNATIONAL JOURNAL OF ACADEMIC RESEARCH IN BUSINESS AND SOCIAL SCIENCES Vol. 11, No. 4, 2021, E-ISSN: 2222-6990 @ 2021 HRMARS

The Result of FDM 2 (item Rank)

Table 7: Result of item rank

\begin{tabular}{|c|c|c|c|c|c|c|c|c|c|c|c|c|c|c|c|c|c|c|}
\hline \multirow[b]{2}{*}{$\begin{array}{l}\text { List of } \\
\text { expert }\end{array}$} & \multicolumn{8}{|c|}{ Social Factor } & \multicolumn{5}{|c|}{ Cognitive factor } & \multicolumn{5}{|c|}{ Emotional Factor } \\
\hline & Item1 & Item2 & $\begin{array}{c}\text { Item } \\
\mathbf{3} \\
\end{array}$ & $\begin{array}{c}\text { Item } \\
4 \\
\end{array}$ & $\begin{array}{c}\text { Item } \\
5 \\
\end{array}$ & $\begin{array}{c}\text { Item } \\
6 \\
\end{array}$ & $\begin{array}{c}\text { Item } \\
7 \\
\end{array}$ & $\begin{array}{l}\text { Ite } \\
\text { m8 }\end{array}$ & \begin{tabular}{|c} 
Item \\
1 \\
\end{tabular} & $\begin{array}{c}\text { Item } \\
2 \\
\end{array}$ & $\begin{array}{c}\text { Item } \\
\mathbf{3} \\
\end{array}$ & $\begin{array}{c}\text { Item } \\
4 \\
\end{array}$ & $\begin{array}{c}\text { Item } \\
5 \\
\end{array}$ & \begin{tabular}{|c|} 
Item \\
1 \\
\end{tabular} & $\begin{array}{c}\text { Item } \\
2 \\
\end{array}$ & $\begin{array}{c}\text { Item } \\
3 \\
\end{array}$ & $\begin{array}{c}\text { Item } \\
4 \\
\end{array}$ & $\begin{array}{c}\text { Item } \\
5 \\
\end{array}$ \\
\hline & 0.078 & 0.052 & 0.04 & 0.08 & 0.01 & 0.04 & 0.02 & 0.02 & 0.01 & 0.04 & 0.02 & 0.04 & 0.02 & 0.22 & 0.01 & 0.01 & 0.02 & 0.03 \\
\hline \multirow[t]{2}{*}{ Expert1 } & 73 & 49 & 724 & 923 & 05 & 199 & 099 & 099 & 575 & 724 & 099 & 199 & 099 & 044 & 575 & 575 & 624 & 674 \\
\hline & 0.209 & 0.052 & 0.01 & 0.19 & 0.01 & 0.01 & 0.03 & 0.02 & 0.04 & 0.12 & 0.02 & 0.01 & 0.02 & 0.01 & 0.01 & 0.01 & 0.02 & 0.02 \\
\hline \multirow[t]{2}{*}{ Expert2 } & 95 & 49 & 05 & 945 & 05 & 575 & 674 & 099 & 199 & 597 & 099 & 575 & 099 & 05 & 575 & 575 & 624 & 099 \\
\hline & 0.020 & 0.052 & 0.04 & 0.08 & 0.01 & 0.04 & 0.03 & 0.02 & 0.04 & 0.01 & 0.02 & 0.01 & 0.02 & 0.06 & 0.01 & 0.01 & .02 & 0.03 \\
\hline \multirow[t]{2}{*}{ Expert3 } & 99 & 49 & 724 & 923 & 05 & 199 & 674 & 099 & 199 & 05 & 099 & 575 & 099 & 823 & 575 & 575 & 624 & 674 \\
\hline & 0.020 & 0.005 & 0.04 & 0.08 & 0.04 & 0.04 & 0.03 & 0.02 & 0.24 & 0.04 & 0.02 & 0.04 & 0.03 & 0.01 & 0.04 & 0.01 & 0.02 & 0.03 \\
\hline \multirow[t]{2}{*}{ Expert4 } & 99 & 25 & 724 & 398 & 724 & 199 & 674 & 099 & 669 & 724 & 099 & 99 & 674 & 05 & 99 & 75 & 624 & 674 \\
\hline & 0.094 & 0.005 & 0.04 & 0.08 & 0.24 & 0.13 & 0.13 & 0.02 & 0.04 & 0.01 & 0.02 & 0.24 & 0.02 & 0.01 & 0.04 & 0.04 & 0.02 & 0.03 \\
\hline \multirow[t]{2}{*}{ Expert5 } & 48 & 25 & 724 & 398 & 144 & 122 & 646 & 099 & 199 & 05 & 099 & 669 & 099 & 05 & 199 & 199 & 624 & 674 \\
\hline & 0.078 & 0.120 & 0.01 & 0.08 & 0.01 & 0.04 & 0.02 & 0.03 & 0.01 & 0.04 & 0.02 & 0.04 & 0.02 & 0.10 & 0.13 & 0.01 & 0.03 & 0.02 \\
\hline \multirow[t]{2}{*}{ Expert6 } & 73 & 72 & 05 & 923 & 05 & 199 & 099 & 674 & 575 & 724 & 099 & 199 & 099 & 497 & 122 & 575 & 149 & 099 \\
\hline & 0.020 & 0.052 & 0.01 & 0.08 & 0.04 & 0.04 & 0.03 & 0.02 & 0.01 & 0.01 & 0.15 & 0.01 & 0.02 & 0.06 & 0.01 & 0.01 & 0.02 & 0.02 \\
\hline \multirow[t]{2}{*}{ Expert7 } & 99 & 49 & 05 & 398 & 724 & 199 & 674 & 099 & 575 & 05 & 221 & 575 & 099 & 823 & 575 & 575 & 624 & 099 \\
\hline & 0.078 & 0.005 & 0.12 & 0.08 & 0.04 & 0.01 & 0.02 & 0.03 & 0.04 & 0.04 & 0.03 & 0.04 & 0.03 & 0.01 & 0.04 & 0.04 & 0.14 & 0.13 \\
\hline \multirow[t]{2}{*}{ Expert8 } & 73 & 25 & 597 & 923 & 724 & 575 & 099 & 674 & 199 & 724 & 674 & 199 & 674 & 05 & 199 & 199 & 696 & 646 \\
\hline & 0.078 & 0.120 & 0.04 & 0.08 & 0.04 & 0.01 & 0.03 & 0.03 & 0.04 & 0.04 & 0.02 & 0.04 & 0.03 & 0.06 & 0.01 & 0.01 & 0.03 & 0.02 \\
\hline \multirow[t]{2}{*}{ Expert9 } & 73 & 72 & 724 & 923 & 724 & 575 & 674 & 674 & 199 & 724 & 099 & 199 & 674 & 823 & 575 & 575 & 149 & 099 \\
\hline & 0.020 & 0.005 & 0.04 & 0.08 & 0.04 & 0.01 & 0.02 & 0.03 & 0.04 & 0.12 & 0.02 & 0.04 & 0.03 & 0.01 & 0.04 & 0.01 & 0.02 & 0.03 \\
\hline \multirow[t]{2}{*}{ Expert10 } & 99 & 25 & 724 & 398 & 724 & 575 & 099 & 674 & 199 & 597 & 099 & 199 & 674 & 05 & 199 & 575 & 624 & 674 \\
\hline & 0.094 & 0.052 & 0.12 & 0.08 & 0.04 & 0.01 & 0.03 & 0.02 & 0.04 & 0.04 & 0.02 & 0.04 & 0.02 & 0.06 & 0.04 & 0.04 & 0.02 & 0.03 \\
\hline \multirow[t]{2}{*}{ Expert11 } & 48 & 49 & 597 & 923 & 724 & 575 & 674 & 099 & 199 & 724 & 099 & 199 & 099 & 823 & 199 & 199 & 624 & 674 \\
\hline & & & Item & Item & Item & Item & Item & Ite & Item & Item & Item & Item & Item & Item & Item & Item & Item & Item \\
\hline Statistics & Item1 & Item2 & 3 & 4 & 5 & 6 & 7 & 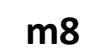 & 1 & 2 & 3 & 4 & 5 & 1 & 2 & 3 & 4 & 5 \\
\hline
\end{tabular}


INTERNATIONAL JOURNAL OF ACADEMIC RESEARCH IN BUSINESS AND SOCIAL SCIENCES Vol. 11, No. 4, 2021, E-ISSN: $2222-6990 @ 2021$ HRMARS

\begin{tabular}{|c|c|c|c|c|c|c|c|c|c|c|c|c|c|c|c|c|c|c|}
\hline $\begin{array}{l}\text { Value of } \\
\text { the item }\end{array}$ & $\begin{array}{c}0.072 \\
53\end{array}$ & $\begin{array}{c}0.047 \\
72\end{array}$ & $\begin{array}{l}0.05 \\
153\end{array}$ & $\begin{array}{l}0.09 \\
734\end{array}$ & $\begin{array}{l}0.05 \\
153\end{array}$ & $\begin{array}{l}0.03 \\
817\end{array}$ & $\begin{array}{l}0.04 \\
008\end{array}$ & $\begin{array}{l}0.02 \\
672\end{array}$ & $\begin{array}{r}0.05 \\
344\end{array}$ & $\begin{array}{r}0.05 \\
153\end{array}$ & $\begin{array}{r}0.03 \\
435\end{array}$ & $\begin{array}{r}0.05 \\
344\end{array}$ & $\begin{array}{r}0.02 \\
672\end{array}$ & $\begin{array}{l}0.05 \\
917\end{array}$ & $\begin{array}{l}0.03 \\
817\end{array}$ & $\begin{array}{l}0.02 \\
291\end{array}$ & $\begin{array}{l}0.03 \\
817\end{array}$ & $\begin{array}{l}0.04 \\
008\end{array}$ \\
\hline $\begin{array}{c}\text { Value of } \\
\text { the } \\
\text { construct }\end{array}$ & & & & 0.053 & & & & & & & 0.0439 & & & & & 0.0397 & & \\
\hline Item $<0.2$ & 10 & 11 & 11 & 11 & 10 & 11 & 11 & 11 & 10 & 11 & 11 & 10 & 11 & 10 & 11 & 11 & 11 & 11 \\
\hline $\begin{array}{c}\% \text { of item } \\
<0.2\end{array}$ & $90 \%$ & $100 \%$ & $\begin{array}{c}100 \\
\% \\
\end{array}$ & $\begin{array}{c}100 \\
\%\end{array}$ & $90 \%$ & $\begin{array}{c}100 \\
\% \\
\end{array}$ & $\begin{array}{c}100 \\
\% \\
\end{array}$ & $\begin{array}{c}100 \\
\% \\
\end{array}$ & 0.9 & 1 & 1 & 0.9 & 1 & 0.9 & 1 & 1 & 1 & 1 \\
\hline $\begin{array}{c}\text { Average } \\
\text { of } \% \\
\text { consensus }\end{array}$ & \multicolumn{8}{|c|}{97} & \multicolumn{5}{|c|}{96} & \multicolumn{5}{|c|}{98} \\
\hline $\begin{array}{l}\text { Defuzzific } \\
\text { ation }\end{array}$ & $\begin{array}{c}0.863 \\
64\end{array}$ & $\begin{array}{c}0.909 \\
09\end{array}$ & $\begin{array}{l}0.91 \\
818\end{array}$ & $\begin{array}{c}0.84 \\
545\end{array}$ & $\begin{array}{l}0.91 \\
818\end{array}$ & $\begin{array}{l}0.92 \\
727\end{array}$ & $\begin{array}{l}0.93 \\
636\end{array}$ & $\begin{array}{l}0.93 \\
636\end{array}$ & $93 \%$ & $92 \%$ & $96 \%$ & $93 \%$ & $96 \%$ & $\begin{array}{l}0.88 \\
182\end{array}$ & $\begin{array}{l}0.92 \\
727\end{array}$ & $\begin{array}{l}0.97 \\
273\end{array}$ & $\begin{array}{l}0.95 \\
455\end{array}$ & $\begin{array}{l}0.93 \\
636\end{array}$ \\
\hline Ranking & 5 & 4 & 3 & 6 & 3 & 2 & 1 & 1 & 2 & 3 & 1 & 2 & 1 & 5 & 4 & 1 & 2 & 3 \\
\hline Status & $\begin{array}{c}\text { Accep } \\
t\end{array}$ & $\begin{array}{c}\text { Accep } \\
t\end{array}$ & $\begin{array}{c}\text { Acce } \\
\text { pt }\end{array}$ & $\begin{array}{c}\text { Acce } \\
\text { pt }\end{array}$ & $\begin{array}{c}\text { Acce } \\
\text { pt }\end{array}$ & $\begin{array}{c}\text { Acce } \\
\text { pt }\end{array}$ & $\begin{array}{c}\text { Acce } \\
\text { pt }\end{array}$ & $\begin{array}{l}\text { Acc } \\
\text { ept }\end{array}$ & $\begin{array}{c}\text { Acce } \\
\mathrm{pt}\end{array}$ & $\begin{array}{c}\text { Acce } \\
\text { pt }\end{array}$ & $\begin{array}{c}\text { Acce } \\
\mathrm{pt}\end{array}$ & $\begin{array}{c}\text { Acce } \\
\text { pt }\end{array}$ & $\begin{array}{c}\text { Acce } \\
\text { pt }\end{array}$ & $\begin{array}{c}\text { Acce } \\
\text { pt }\end{array}$ & $\begin{array}{c}\text { Acce } \\
\text { pt }\end{array}$ & $\begin{array}{c}\text { Acce } \\
\mathrm{pt}\end{array}$ & $\begin{array}{c}\text { Acce } \\
\text { pt }\end{array}$ & $\begin{array}{c}\text { Acce } \\
\mathrm{pt}\end{array}$ \\
\hline
\end{tabular}


Table 8: Elements Rank

\begin{tabular}{|c|l|l|l|}
\hline \multirow{4}{*}{$\begin{array}{c}\text { I-CyLearn } \\
\text { Framework }\end{array}$} & \multicolumn{1}{|c|}{ Construct } & \multicolumn{1}{|c|}{ Early elements Rank } & \multicolumn{1}{c|}{$\begin{array}{c}\text { New Elements } \\
\text { Ranking }\end{array}$} \\
\cline { 2 - 4 } & Emotional Factor & EF1, EF2, EF3, EF4, EF5 & EF3, EF4, EF5, EF1, EF2 \\
\cline { 2 - 4 } & Cognitive factor & C1, C2, C3, C4, C5 & C3, C5, C4, C1, C2 \\
\cline { 2 - 5 } & Social factor & $\begin{array}{l}\text { SF1, SF2, SF3, SF4, } \\
\text { SF5,SF6,SF7,SF8 }\end{array}$ & $\begin{array}{l}\text { SF2, SF8, SF6, SF5,SF3, SF1,SF4 } \\
\text { SF2, SF }\end{array}$ \\
\hline
\end{tabular}

Table 9: The final I-CyLearn framework in Islamic Social Network Learning

\begin{tabular}{|c|c|c|}
\hline & Construct & Final elements \\
\hline & $\begin{array}{l}\text { Emotional } \\
\text { Factor }\end{array}$ & $\begin{array}{l}\text { - Reward processing and reinforcement } \\
\text { - Active maintenance of valence information } \\
\text { - Increase active response to positive emotion } \\
\text { - Lecturer control social emotional interaction } \\
\text { - Detection of emotional conflict }\end{array}$ \\
\hline $\begin{array}{l}\text { I-CyLearn } \\
\text { Framework }\end{array}$ & Cognitive factor & $\begin{array}{l}\text { - Intellectual developments (Optimizing the } \\
\text { Students critical thinking) } \\
\text { - Openness principle (Lecturer play as facilitator to } \\
\text { guide and facilitate students) } \\
\text { - Interaction principle (Interaction between } \\
\text { students and lecturer by conducting the form of } \\
\text { question and answer given by the students) } \\
\text { - Asking principle (Lecturer ask the students to } \\
\text { encourage student participation) } \\
\text { - Learning to think principle (Lecturer emphasized } \\
\text { students thinking skills by maximizing the use of } \\
\text { brain) }\end{array}$ \\
\hline & Social factor & $\begin{array}{l}\text { Reinforcement. The lecturer gives some } \\
\text { responses to reinforce positive refection \& reports } \\
\text { of the students } \\
\text { - Evaluation. The Lecturer evaluates students } \\
\text { report, performance \& attitude } \\
\text { - Reflection, reporting \& presentation. Students } \\
\text { make reflections of the completed activities, make } \\
\text { reports in the classroom. } \\
\text { - Preparing \& giving a presentation. Students } \\
\text { thanks their learning partners \& giving them } \\
\text { presents } \\
\text { Delivering the assignment of observation \& the } \\
\text { rule of practice. The lecturer explains the rules } \\
\text { consisting of: Goal of activity, pairing the students, } \\
\text { procedure, time allocation for the activity } \\
\text { Finding the learning partner. Students } \\
\text { autonomously find their learning partners around } \\
\text { the campus or their houses }\end{array}$ \\
\hline
\end{tabular}




\begin{tabular}{|l|l|}
\hline & $\begin{array}{l}\text { Initial Observation. Students introduce } \\
\text { themselves \& their objectives to their learning } \\
\text { partners \& negotiate time and procedure of the } \\
\text { participatory observation }\end{array}$ \\
\hline
\end{tabular}

\section{Conclusion}

As the rest of the world begins to use technology effectively in all sectors including in the education system. In line with the currents needs, educational institutions in Malaysia are beginning to adapt e learning or digital learning effectively as it more flexible, fast and facilitates the delivery of information in line with the governments requirements to encourage informations sharing. Due to its versatility and accesability, e learning can provide a new dimension of education. E learning will possibly become an excellent interactive education platform in the future because it will increase the quality of education and participation in our formal education. Systems. Furthermore, E learning is a key part of versatility by giving students and educators the opportunity to choose where and when they are teaching or leraning according to their professional and personal needs (Chang \& Chang; Rani \& Kant, 2013). Based on this scenario, the need for a specific guideline or framework to be used as a basic guide in filling online learning activities should be formed to facilitate educators in implementing their teaching and learning. Finally, the researcher managed to produce a basic framework in the implementation of online learning in the context of higher education in Malaysia or in other part of the globe.

\section{Guideline for Future Research}

This study basically uses developmental design research. Therefore, future researcher can use other research methods such as quantitative or qualitative to obtain more in depth data. Moreover, this study also uses a Fuzzy Delphi method that specailised in expert consensus, therefore future research can use other methods to obtain more generalized results. If more specific, future reseachers can adapt this research framework to form a module or research model that can be utilized in the same field in the future.

\section{Reference}

Adler, M., \& Ziglio, E. (1996). Gazing into the Oracle: The Delphi method and its application to social policy and public health: Jessica Kingsley Publisher

Al-Emran, M., \& Mezhuyev, V. (2019). Examining the Effect of Knowledge Management Factors on Mobile Learning Adoption Through the Use of Importance-Performance Map Analysis (IPMA). In International Conference on Advanced Intelligent Systems and Informatics (pp. 449-458). Springer.

Al-Emran, M., \& Teo, T. (2019). Do knowledge acquisition and knowledge sharing really affect e-learning adoption? An empirical study. Education and Information Technologies. https://doi.org/10.1007/s10639-019-10062-w

Bodjanova, S. (2006). Median alpha-levels of a fuzzy number. Fuzzy Sets and Systems, 157(7), 879-891. doi: 10.1016/j.fss.2005.10.015

Belmonte, J. L., Segura-Robles, A., Moreno-Guerrero, A. J., \& Parra-González, M. E. (2020). Machine learning and big data in the impact literature. A bibliometric review with scientific mapping in web of science. Symmetry. https://doi.org/10.3390/SYM12040495

Cantrill, J. A., Sibbald, B., \& Buetow, S. (1996). The Delphi and nominal group techniques in health services research. International Journal of Pharmacy Practice, 4(2), 67-74. 
Chang, P.-L., Hsu, C.-W., \& Chang, P.-C. (2011). Fuzzy Delphi Method for evaluating hydrogen production technologies. International Journal of Hydrogen Energy, 36(21), 1417214179. doi:10.1016/j.ijhydene.2011.05.045

Chang, I. Y., \& Chang, W. Y. (2012). Effects of E-learning on learning performance - A case study on students in tourism department in Taiwan. Pakistan Journal of Statistics.

Cheok, M. L., \& Wong, S. L. (2014). Teachers' perceptions of E-learning in Malaysian secondary schools. Proceedings of the 22nd International Conference on Computers in Education, ICCE 2014.

Dalkey, N., \& Helmer, O. (1963). An Experimental Application of the Delphi Method to the Use of Experts. Management Science.

Daud, W. A. A. W., Teck, W. K., Ghani, M. T. A., \& Ramli, S. (2019). The Needs Analysis of Developing Mobile Learning Application for Cybergogical Teaching and Learning of Arabic Language Proficiency. International Journal of Academic Research in Business and Social Sciences. https://doi.org/10.6007/ijarbss/v9-i8/6206

Dailey-Hebert, A., \& Dennis, K. S. (2015). Transformative perspectives and processes in higher education. In Transformative Perspectives and Processes in Higher Education. https://doi.org/10.1007/978-3-319-09247-8

Yusuf, Y. Q. (2018). Digital culture and digitagogy: a life of a digital culturalist and a digitagogist. The Roles of Parents in Shaping Children's Characters (ICECED).

Hasson, F., Keeney, S., \& McKenna, H. (2000). Research guidelines for the Delphi survey technique. Journal of Advanced Nursing. https://doi.org/10.1046/j.1365-2648.2000.t011-01567.x

Hsieh, T. Y., Lu, S. T., \& Tzeng, G. H. (2004). Fuzzy MCDM approach for planning and design tenders selection in public office buildings. International Journal of Project Management. https://doi.org/10.1016/j.ijproman.2004.01.002

Hubalovsky, S., Hubalovska, M., \& Musilek, M. (2019). Assessment of the influence of adaptive E-learning on learning effectiveness of primary school pupils. Computers in Human Behavior. https://doi.org/10.1016/j.chb.2018.05.033

Linstone, H. A., \& Turoff, M. (2002). The Delphi Method - Techniques and Applications. The Delphi method - Techniques and applications.

Kasim, N. N. M., \& Khalid, F. (2016). Choosing the right learning management system (LMS) for the higher education institution context: A systematic review. International Journal of Emerging Technologies in Learning. https://doi.org/10.3991/ijet.v11i06.5644

Kim, S.-E., Lee, K. Y., Shin, S. II, \& Yang, S.-B. (2017). Effects of tourism information quality in social media on destination image formation: The case of Sina Weibo. Information \& Management, 54(6), 687-702

Basak, K. S., Wotto, M., \& Bélanger, P. (2018). E-learning, M-learning and D-learning: Conceptual definition and comparative analysis. E-Learning and Digital Media. https://doi.org/10.1177/2042753018785180

Mustapha, R., \& Darusalam, G. (2017). Aplikasi kaedah Fuzzy Delphi dalam Kajian Sians Sosial. Penerbitan Universiti Malaya. Kuala Lumpur

J. Skulmoski, G., T. Hartman, F., \& Krahn, J. (2007). The Delphi Method for Graduate Research. Journal of Information Technology Education: Research. https://doi.org/10.28945/199

Perera, A. H., Drew, C. A., \& Johnson, C. J. (2012). Expert Knowledge and Its Application in Landscape Ecology. Springer, New York, 1-11. http://doi.org/10.1007/978-1-4614-1034- 
Philip, R. (2000). New Application for Delphi Technique, Annual "San Diego" Pfeifer \& Company, Vol 2, 191

Ramos-Morcillo, A. J., Leal-Costa, C., Moral-García, J. E., \& Ruzafa-Martínez, M. (2020). Experiences of nursing students during the abrupt change from face-to-face to e-learning education during the first month of confinement due to COVID-19 in Spain. International Journal of Environmental Research and Public Health. https://doi.org/10.3390/ijerph17155519

Sforza, V. C., \& Ortolano, L. (1984). Delphi forecasts of land use: Transportation interactions. Journal of Transportation Engineering. https://doi.org/10.1061/ (ASCE) 0733-947X (1984)110:3(324)

Tayebinik, M., \& Puteh, M. (2012). Blended Learning or E-learning? International Magazine on Advances in Computer Science and Telecommunications, 3(1), 103-110

Tang, C. W., \& Wu, C. T. (2010). Obtaining a picture of undergraduate education quality: A voice from inside the university. Higher Education. https://doi.org/10.1007/s10734009-9299-5

Uppal, M. A., Ali, S., \& Gulliver, S. R. (2018). Factors determining e-learning service quality. British Journal of Educational Technology. https://doi.org/10.1111/bjet.12552 